\title{
Investigation of Primary School Teachers' Perception of Discipline Types They Use for Classroom Management
}

\author{
Hatice Vatansever Bayraktar ${ }^{1} \&$ M. Cihangir Doğan ${ }^{2}$ \\ ${ }^{1}$ Education Faculty, İstanbul Sabahattin Zaim University, İstanbul, Turkey \\ ${ }^{2}$ Education Faculty, Marmara University, İstanbul, Turkey \\ Correspondence: Hatice Vatansever Bayraktar, Education Faculty, İstanbul Sabahattin Zaim University, İstanbul, \\ Turkey. E-mail: hatice.bayraktar@izu.edu.tr
}

$\begin{array}{ll}\text { Received: November 17, } 2016 & \text { Accepted: November 30, } 2016 \quad \text { Online Published: January 16, } 2017 \\ \text { doi:10.5539/hes.v7n1p30 } & \text { URL: http://dx.doi.org/10.5539/hes.v7n1p30 }\end{array}$

This study is a further developed form of the study presented in the XI.European Conference on Social and Behavioral Sciences held on 1-4 September 2016 as an oral declaration.

\begin{abstract}
The objective of this study is to examine the primary school teachers' the perceptions of discipline types they use for classroom management; and also to find out if there is a statistically significant difference between the perceptions of discipline types used in classroom management according to the demographic characteristics of primary school teachers.

The research is prepared in accordance with the survey model. Population consists of primary school teachers working in İstanbul province in 2015-2016 academic years. As for the sample, it consists of 275 primary school teachers working in Bağcılar, Bahçelievler, Başakşehir, Gaziosmanpaşa and Küçükçekmece districts in İstanbul province in 2015-2016 academic years. Data were collected through "personal information form" and "discipline types that teacher use for classroom management scale". Data were analyzed with SPSS and frequency, percentage, t-test, Mann Whitney-U Test, Kruskal Wallis-H Test were used.

As a result of the study, it was found out that the total perception of primary school teachers regarding the sub-dimensions of the types of discipline they use in classroom management, and their perception of the sub-dimensions of preventive discipline, supportive discipline and corrective discipline are at the level of "totally agree (always)". In general, teachers use all three types of discipline in classroom management. It was seen that primary school teachers prefer most the preventive discipline approach in classroom management, which is followed by the supportive discipline approach. The types of discipline used by primary school teachers in classroom management do not vary significantly by the variables of gender, age, education status and professional seniority. The perceptions of the primary school teachers working at private schools of preventive discipline are higher than those of the primary school teachers working at a state school. Widowed teachers prefer the preventive discipline and corrective discipline practices more than single, married and divorced teachers. Teachers who worked at their school for 16-20 years prefer supportive discipline practices more than teachers who worked at their school for 1-3 years, 4-7 years, 8-10 years and 11-15 years. Teachers who worked at their school for 16-20 years prefer corrective discipline practices more than the teachers who worked at their school for 1-3 years, 4-7 years, and 8-10 years. Furthermore, teachers who worked at their school for 11-15 years prefer corrective discipline practices more than the teachers who worked at their school for 1-3 years.
\end{abstract}

Keywords: primary school teacher, classroom management, discipline, discipline type

\section{Introduction}

Classroom management is the management of the place, students, and sources. Preparing a suitable learning environment, and creating and using the facilities and place, rules, learning scheme and processes are called classroom management. Minimization of learning and trial obstacles, the use of the sources in the best way, performing participatory and practical activities are necessary for a good classroom management (Başar, 2008). 
Classroom management is defined as the use of the moral and material elements in the classroom efficiently and effectively in line with the objectives of the organization. According to another definition, it means that administrative strategies facilitate effective and efficient learning and create the learning environment, and maintaining this (Arslan, 2012; Quoted by Vatansever-Bayraktar, 2015).

Classroom management is a complex structure that allows for the learning of students, ensures that they achieve instructional objectives, consists of the behaviours used by teachers in order to explain and maintain classroom situations and that must be defined step-by-step. For this reason, classroom management is a discipline that is obligatory to know in advance for effective teaching. The skill of the teacher in classroom management is the function to understand the dynamics of effective classroom management (Weber, 1994; Quoted by Kılbaş, 2006).

Gordon (2002) defines the word discipline as "a particular order that is put forth in accordance with previously defined rules, and the behaviours put forth by individuals in this direction".

The main objective of discipline is to ensure that individuals are in harmony both with themselves and the environment by introducing them certain habits and to maintain the moral development of individuals with the sense of responsibility (Yavuzer, 2003).

According to Yiğit (2004), the main objective of discipline is to facilitate learning. That there are certain rules and people obey these rules are indispensable in places where people live collectively. Classroom rules consist of certain previously defined principles in order to guide the behaviours of students.

Discipline is that individuals or groups take their behaviours under control in order to achieve the objectives of education (Alıcı̈üzel, 1979; Quoted by Esen, 2006).

With reference to Whitehead, it is concluded that discipline in schools ought to be arranged so as to help pupils foster wisdom for life, as this concept integrates liberal knowledge and educational interest (MacAllister, 2013).

Debate about "discipline" in schools almost invariably takes the form of empirical enquiry about which methods are most effective in securing it. This is to neglect a substantial part of the problem-the prior moral issue about the proper way to educate children. The main difficulties here are conceptual. Two rival ways of conceptualising "educational order" are identified and examined in the study titled "Disciplin in Schools". The received, traditional way is found to be disingenuous, incoherent and unworkable. The alternative-a reconstructed child-centred approach escapes these problems and is commended. This conclusion is tested by investigating how each maps on to the project of moral education, for which school discipline is a neglected central arena (Clark, 1998).

In the study titled "Why discipline needs to be reclaimed as an educational concept" it considers different conceptualisations of school discipline within both UK education policy and wider educational and philosophical literature. Initially, it is noted that notions of "behaviour management" dominate discourses about school discipline. It is suggested that this is unhelpful as behaviour management skills are underpinned by a behaviourist understanding of learning that denies pupils an important degree of agency over their own development-pupils are rather portrayed as unruly and morally deficient. It is therefore maintained that discipline needs to be reclaimed as an educational concept as it can be a valuable personal quality whose possession indicates a capacity to set important goals for oneself and see them through even in the face of difficulty. With reference to the diverse philosophies of Dewey, Wilson, Durkheim, Oakeshott, and MacMurray, it is contended that a re-conceived notion of school discipline might enable less controlling and behaviourist and more educational discipline in at least three ways: the ethical (by guiding the ethical development of pupils), the humanising (by encouraging pupils to act for the sake of others rather than only think about themselves) and the epistemic (by supporting pupils to engage in the pursuit of valued interests and knowledge) (MacAllister, 2014).

Teachers believe that the key to the success desired in a classroom environment is classroom discipline. Discipline is a very important element for students to achieve the required academic success. The uncertainty in the classroom environment decreases, and random behaviours are eliminated thanks to discipline (Helvac1, 2010).

The main objective of the discipline approach is to prevent negative student behaviours. Although discipline is used with different meanings, it simply means the ways of controlling the negative behaviours in the classroom by the teacher (Lefrançois, 1995; quoted by Erden, 2008, p. 15).

Preventive Discipline: "Practices for preventing the behaviour that will cause discipline problem in the classroom" (Esen, 2006, p. 7). The precautionary model includes taking the precautions for not causing a reaction and the undesired situation causing a reaction, and not deviating from the desired situation. The 
arrangements in the education process should be made by planning in advance and taking the precautions by overseeing the possibilities. When this array of plans, programs and rules is carefully used, the reactional model, and the additional time and source burdens brought about by it will not be required (Başar, 2008).

Supportive Discipline: To intervene with the student with supportive and motivating interventions against the behaviours that may cause discipline problems in the classroom (Esen, 2006).

Corrective Discipline: "Practices for correcting the unwanted behaviours that occur in the classroom despite all preventive and supportive efforts" (Esen, 2006, p. 7).

Palardy (1995) puts forth 9 strategies for preventing discipline problems in the classroom:

1) They should be relaxed about themselves, their students and subject areas.

2) They should believe in the behaviours of their students in regard to suitable classroom behaviours.

3) They should ensure the interest in the learning activities.

4) They should combine the capacities of students and learning activities and requirements.

5) They should create the rules together with students.

6) They should ensure that students know and understand the routine works.

7) Problem times should be determined.

8) They should not forget that students are not adults.

9) They should show that they actually respect students (Quoted by Aydın, 2001, pp. 70-71).

Teachers with the supportive discipline style have high features of supportive features, while they have low properties of the coercive style. These teachers develop a student-centred and close relationship. They show effort in order to talk to the student about a discipline problem. They are very tolerant towards discipline acts (Tomal, 1999; quoted by İnce, 2011, p. 37).

Corrective-reactive discipline has an understanding that foresees the suitable reaction towards undesired behaviours. Interventions are made in order to be able to eliminate undesired behaviours when they occur. In this case, the reward and punishment come to the forefront. It is essential to use positive reinforcers against undesired behaviours (Yalçınkaya \& Küçükkaragöz, 2006). Reactive model is one of the indispensable models of classroom management, which is the most beneficial to use when the reaction is necessary, as well as being an old model. As can be understood from its name, this model includes showing reactions against a situation, formation or behaviour. It is used in such a way that it generally includes reward or punishment type sanctions in order to ensure the return to the desired state. It is suggested that punishment includes new arrangements that take to the new targeted situation instead of the punishment, in order to eliminate the negativities of the counter-reaction of punishment (Başar, 2008).

Upon examining the literature on the subject, the studies titled "The understanding of discipline and discipline practices of the teachers working in vocational high schools" carried out by Güner (2009), "The understanding of discipline and discipline methods used by primary school 4th and 5th grade teachers (Konya province example)" carried out by Bal (2005), "The attitudes of teachers towards discipline and the understanding of discipline in the total quality model" carried out by Tosun (2001), "Assessment of the discipline practices in secondary school institutions according to the provisions of the legislation on discipline in secondary education institutions" carried out by Uysal (1991), "Assesment of the award and punishment methods used by the class teachers to ensure discipline in the class" carried out by Yllmaz (2007), "The opinion of managers and teachers on discipline problems at elementary schools" carried out by Çimen and Karaboğa (2015), "Opinions of pre-service teachers on the discipline models used in classroom management" carried out by Koç (2011), "Discipline approaches of school managers" carried out by Büyüksarı (2015), "Relationship between the school culture perceptions of secondary school teachers and the types of discipline they use in school management" carried out by Kartal (2014), "Examination of the relationship between the humour styles and understandings of discipline of school managers in terms of teacher opinions" carried out by Mert (2014), "Investigation of School Administrators' Attitude with Discipline Problems" carried out by Vatansever-Bayraktar and Kaya (2016), "Attitudes of religious culture and moral knowledge teachers towards student behaviours that disrupt the discipline" carried out by Güzel (2014), "Key factors that enable the successful management of difficult behaviour in schools and classrooms" carried out by Visser (2005), "Classroom behaviour management: educational psychologists' views on effective practice" carried out by Hart (2010), "Using rewards and sanctions in the classroom: pupils' perceptions of their own responses to current behaviour management strategies" carried 
out by Payne (2015), "Behaviour, classroom management and student 'control': enacting policy in the English secondary school" carried out by Maguire, Ball and Braun (2010), "Strategies for developing positive behaviour management. Teacher behaviour outcomes and attitudes to the change process" carried out by Hayes, Hindle and Withington (2007), "Whole-school positive behaviour support: effects on student discipline problems and academic performance" carried out by Luiselli et al. (2005), "The measurement of classroom managementself-efficacy: a review of measurement instrument development and influences" carried out by O'neill and Stephenson (2011) and "Classroom management: a critical part of educational psychology, with implications for teacher education" carried out by Emmer and Stough (2001) were encountered. However, no study that examines the perceptions of primary school teachers of the types of discipline they use in classroom management was encountered. In this context, it is believed that this study that is carried out in order to determine the level of the perceptions of primary school teachers in classroom management of the types of discipline and whether they differ by different variables will contribute to the field.

\subsection{Purpose of the Study}

The aim of this study is to investigate the level of perception of primary school teachers regarding the types of discipline they use in classroom management, and whether their perceptions of the types of discipline they use in classroom management vary by the variables of gender, age, marital status, status of education, the type of school they work at, the status of professional seniority and the period they work at their school.

\section{Method}

\subsection{Research of Model}

Survey model was used in this study as to examine the primary school teachers' the perceptions of discipline types they use for classroom management. The survey model was used in the study. Survey models are approaches that aim to describe the past or existing situation as it is (Karasar, 2012).

\subsection{Universe and Sample}

The universe of the study is made up of the primary school teachers working in Istanbul in the 2015-2016 academic years. The sample of the study consists of 275 primary school teachers working in Gaziosmanpaşa, Bağcılar, Küçükçekmece and Başakşehir districts of Istanbul.

\subsection{Data Collection Tools}

The "Scale on the Types of Discipline Used by Teachers in Classroom Management" developed by Esen (2006) was used as a data collection tool in the study. The scale consists of three dimensions as preventive, supportive and corrective discipline practices.

In the scale on the types of discipline developed by Esen (2006), the Cronbach's alpha coefficient was found to be $\alpha=.86$ in the discipline sub-dimension, $\alpha=.84$ in the corrective discipline sub-dimension and $\alpha=0.81$ in the preventive discipline sub-dimension.

\subsection{Data Analysis}

The level of the perceptions of the types of discipline used by classroom teachers in classroom management was defined by using arithmetic mean and standard deviation.

The T-test was used in order to determine whether the perceptions of primary schools regarding the types of discipline they use in classroom management differ by the gender variable; the Mann-Whitney U test was used in order to determine whether it varies by the school type variable; ANOVA test was used in order to determine whether it varies by the professional seniority state variable; and the Kruskal-Wallis H Test was used in order to determine whether it varies by the variables of gender, marital status, education status and the period they work at their school.

\section{Findings}

Table 1. Findings on the gender of primary school teachers

\begin{tabular}{ccccc}
\hline Gender & Frequency & Percent & Valid Percent & Cumulative Percent \\
\hline Woman & 191 & 69.5 & 69.5 & 69.5 \\
Erkek & 84 & 30.5 & 30.5 & 100.0 \\
Total & 275 & 100.0 & 100.0 & \\
\hline
\end{tabular}


Findings on the variable of the gender of primary school teachers participating in the study are shown in Table 1. $69.5 \%$ of the primary school teachers are females while $30.5 \%$ are males.

Table 2. Findings on the ages of primary school teachers

\begin{tabular}{ccccc}
\hline Age & Frequency & Percent & Valid Percent & Cumulative Percent \\
\hline $21-25$ & 30 & 10.9 & 10.9 & 10.9 \\
$26-30$ & 59 & 21.5 & 21.5 & 32.4 \\
$31-35$ & 77 & 28.0 & 28.0 & 60.4 \\
$36-40$ & 46 & 16.7 & 16.7 & 77.1 \\
$41-45$ & 31 & 11.3 & 11.3 & 88.4 \\
$46-50$ & 19 & 6.9 & 6.9 & 95.3 \\
51 and over & 13 & 4.7 & 4.7 & 100.0 \\
Total & 275 & 100.0 & 100.0 &
\end{tabular}

Findings on the variable of the age of primary school teachers participating in the study are shown in Table 2 . $10.9 \%$ of the primary school teachers are in the interval between 21 and 25 years, $21.5 \%$ are between 26 and 30 years, $28 \%$ are between 31 and 35 years, $16.7 \%$ are between 36 and 40 years, $11.3 \%$ are between 41 and 45 years, $6.9 \%$ are between 46 and 50 years, and $4.7 \%$ are 51 years old and over.

Table 3. Findings on the marital status of primary school teachers

\begin{tabular}{ccccc}
\hline Marital Status & Frequency & Percent & Valid Percent & Cumulative Percent \\
\hline Single & 79 & 28.7 & 28.7 & 28.7 \\
Married & 185 & 67.3 & 67.3 & 96.0 \\
Widowed & 5 & 1.8 & 1.8 & 97.8 \\
Divorced & 6 & 2.2 & 2.2 & 100.0 \\
Total & 275 & 100.0 & 100.0 & \\
\hline
\end{tabular}

Findings on the variable of the marital status of primary school teachers participating in the study are shown in Table $3.28 .7 \%$ of the primary school teachers are single, $67.3 \%$ are married, $1.8 \%$ are widowed and $2.2 \%$ are divorced.

Table 4. Findings on the status of education of primary school teachers

\begin{tabular}{ccccc}
\hline Status of Education & Frequency & Percent & Valid Percent & Cumulative Percent \\
\hline Associate degree & 14 & 5.1 & 5.1 & 5.1 \\
Bachelor's degree & 230 & 83.6 & 83.6 & 88.7 \\
Master's degree & 31 & 11.3 & 11.3 & 100.0 \\
Total & 275 & 100.0 & 100.0 & \\
\hline
\end{tabular}

Findings on the variable of the status of education of primary school teachers participating in the study are shown in Table $4.5 .1 \%$ of primary school teachers are associate degree, $83.6 \%$ are bachelor's degree and $11.3 \%$ are master's degree graduates. 
Table 5. Findings on the type of school where primary school teachers work

\begin{tabular}{ccccc}
\hline Type of School & Frequency & Percent & Valid Percent & Cumulative Percent \\
\hline State school & 250 & 90.9 & 90.9 & 90.9 \\
Private school & 25 & 9.1 & 9.1 & 100.0 \\
Total & 275 & 100.0 & 100.0 & \\
\hline
\end{tabular}

The findings on the variable of the type of school where primary school teachers participating in the study work are found in Table $5.90 .9 \%$ of primary school teachers work at state schools, while $9.1 \%$ work at private school.

Table 6. Findings on the professional seniority of primary school teachers

\begin{tabular}{ccccc}
\hline Professional Seniority & Frequency & Percent & Valid Percent & Cumulative Percent \\
\hline 1-5 year & 72 & 26.2 & 26.2 & 26.2 \\
6-10 year & 81 & 29.5 & 29.5 & 55.6 \\
11-15 year & 51 & 18.5 & 18.5 & 74.2 \\
16-20 year & 37 & 13.5 & 13.5 & 87.6 \\
21 year and over & 34 & 12.4 & 12.4 & 100.0 \\
Total & 275 & 100.0 & 100.0 & \\
\hline
\end{tabular}

There are findings on the variable of professional seniority of the primary school teachers participating in the study in Table $6.26 .2 \%$ of primary school teachers have $1-5$ years of experience, $29.5 \%$ have $6-10$ years of experience, $18.5 \%$ have $11-15$ years of experience, $13.5 \%$ have $16-20$ years of experience and $12.4 \%$ have 21 and more years of experience.

Table 7. Findings on the period that primary school teachers work at their school

\begin{tabular}{ccccc}
\hline $\begin{array}{c}\text { The Period That Primary School } \\
\text { Teachers Work at Their School }\end{array}$ & Frequency & Percent & Valid Percent & Cumulative Percent \\
\hline $1-3$ year & 149 & 54.2 & 54.2 & 54.2 \\
4-7 year & 76 & 27.6 & 27.6 & 81.8 \\
8-10 year & 25 & 9.1 & 9.1 & 90.9 \\
11-15 year & 14 & 5.1 & 5.1 & 96.0 \\
16-20 year & 6 & 2.2 & 2.2 & 98.2 \\
21 year and over & 5 & 1.8 & 1.8 & 100.0 \\
Total & 275 & 100.0 & 100.0 & \\
\hline
\end{tabular}

The findings on the variable of the period that primary school teachers participating in the study work are presented in Table 7. 54.2\% of primary school teachers worked at the same school for $1-3$ years, $27.6 \%$ worked for 4-7 years, 9.1\% worked for $8-10$ years, $5.1 \%$ worked for $11-15$ years, $2.2 \%$ worked for $16-20$ years, and $1.8 \%$ worked for 21 years and more. 
Table 8 . General averages on the perceptions of primary school teachers regarding the type of discipline used in classroom management

\begin{tabular}{cccc}
\hline Scale and Sub-dimensions & $\mathrm{N}$ & $\mathrm{X}$ & sd \\
\hline Preventive discipline & 275 & 4.4595 & .47904 \\
Supportive discipline & 275 & 4.3898 & .45832 \\
Corrective discipline & 275 & 4.2556 & .58437 \\
Total & 275 & 4.3712 & .45834 \\
\hline
\end{tabular}

According to Table 8 , it was seen that the average of the total perceptions of primary school teachers regarding the sub-dimensions of the types of discipline they use in classroom management is $(X=4.37)$, the average of their perceptions of preventive discipline is $(X=4.45)$, the average of their perceptions of supportive discipline is $(X=4.38)$, the average of their perceptions of corrective discipline is $(X=4.25)$ and at the level of "totally agree (always)". Generally speaking, it can be said that teachers use all three types of discipline in classroom management. It was seen that primary school teachers use the preventive discipline approach most in classroom management, which is followed by the supportive discipline approach.

Table 9. Independent group t-Test results showing the differentiation of the perceptions of primary schools regarding the types of discipline they use in classroom management by the gender variable

\begin{tabular}{|c|c|c|c|c|c|c|c|}
\hline Scale and Sub-dimensions & Gender & $\mathrm{N}$ & $\mathrm{X}$ & sd & $\mathrm{t}$ & df & $\mathrm{p}$ \\
\hline \multirow{2}{*}{ Preventive discipline } & Woman & 191 & 4.4885 & .42820 & 1.517 & 273 & .130 \\
\hline & Man & 84 & 4.3936 & .57575 & & & \\
\hline \multirow{2}{*}{ Supportive discipline } & Woman & 191 & 4.4212 & .38628 & 1.723 & 273 & .086 \\
\hline & Man & 84 & 4.3182 & .58687 & & & \\
\hline \multirow{2}{*}{ Corrective discipline } & Woman & 191 & 4.2502 & .41642 & -.180 & 273 & .857 \\
\hline & Man & 84 & 4.2679 & .85448 & & & \\
\hline \multirow{2}{*}{ Total } & Woman & 191 & 4.3891 & .36886 & .978 & 273 & .329 \\
\hline & Man & 84 & 4.3304 & 61614 & & & \\
\hline
\end{tabular}

As is independent group t-Test seen in Table 9, there is no statistically significant difference in the preventive discipline sub-dimension of the Types of Discipline Scale used by Teachers in Classroom Management by the types of discipline that primary school teachers use in classroom management and their relevant perceptions by the gender variable $[\mathrm{t}(273)=1.517, \mathrm{P}>.05]$; in the sub-dimension of supportive discipline $[\mathrm{t}(273)=1.723, \mathrm{P}>.05]$; in the sub-dimension of corrective discipline $[\mathrm{t}(273)=-.180, \mathrm{P}>.05]$ and the overall scale $[\mathrm{t}(273)=.978, \mathrm{P}>.05]$.

Table 10. The Kruskal-Wallis $\mathrm{H}$ test results showing the differentiation of the perceptions of primary school teachers regarding the types of discipline they use in classroom management by the variable of age

\begin{tabular}{ccccccc}
\hline $\begin{array}{c}\text { Scale and } \\
\text { Sub-dimensions }\end{array}$ & Age & N & Mean Rank & df & X2 & p \\
\hline & $21-25$ & 30 & 130.38 & 6 & 6.373 & .383 \\
& $26-30$ & 59 & 124.90 & & & \\
Preventive discipline & $31-35$ & 77 & 143.35 & & \\
& $36-40$ & 46 & 147.50 & & \\
& $41-45$ & 31 & 158.69 & & \\
& $46-50$ & 19 & 127.79 & & \\
& 51 and over & 13 & 115.31 & & \\
\hline
\end{tabular}




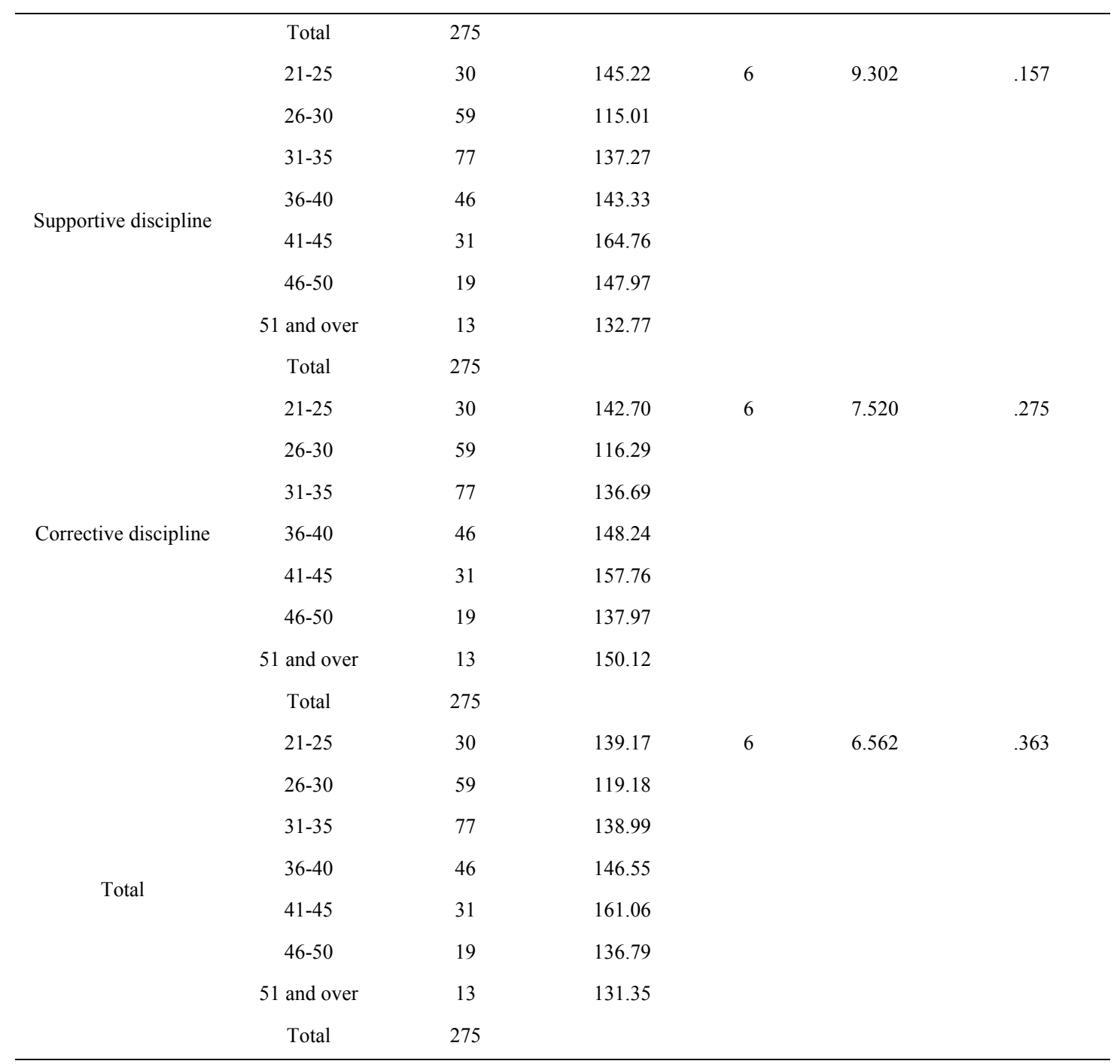

The Kruskal-Wallis $\mathrm{H}$ test results on the preventive discipline, supportive discipline and corrective discipline sub-dimensions of the Types of Discipline Scale Used by Teachers in Classroom Management by the variable of age and the total scores obtained by primary school teachers participating in the study are shown in Table 10.

Accordingly, there is no statistically significant difference between the scores taken by primary school teachers from the "preventive discipline $[\mathrm{X} 2$ (6) $=6.373, \mathrm{P}>.05]$ "; "supportive discipline $[\mathrm{X} 2(6)=9.302, \mathrm{P}>.05]$ "; "corrective discipline $[\mathrm{X} 2(6)=7.520, \mathrm{P}>.05]$ " sub-dimensions of the Scale on the Types of Discipline Used by Teachers in Classroom Management by the variable of age and the total scores they got from the scale [X2 (6) $=6.562, \mathrm{P}>.05]$.

Table 11. The Kruskal-Wallis H Test results showing the differentiation of the perceptions of primary school teachers regarding the types of discipline they use in classroom management by the variable of marital status

\begin{tabular}{|c|c|c|c|c|c|c|c|}
\hline $\begin{array}{c}\text { Scale and } \\
\text { Sub-dimensions }\end{array}$ & Marital Status & $\mathrm{N}$ & Mean Rank & $\mathrm{df}$ & $\mathrm{X} 2$ & $\mathrm{p}$ & $\begin{array}{l}\text { Significant } \\
\text { Difference }\end{array}$ \\
\hline \multirow{5}{*}{ Preventive discipline } & single & 79 & 129.08 & 3 & 8.741 & .033 & 1-3, \\
\hline & married & 185 & 138.88 & & & & $2-3$ \\
\hline & widowed & 5 & 236.20 & & & & $3-4$ \\
\hline & divorced & 6 & 146.67 & & & & \\
\hline & Total & 275 & & & & & \\
\hline
\end{tabular}




\begin{tabular}{|c|c|c|c|c|c|c|c|}
\hline & single & 79 & 132.30 & 3 & 5.639 & .131 & --- \\
\hline & married & 185 & 138.94 & & & & \\
\hline \multirow[t]{5}{*}{ Supportive discipline } & widowed & 5 & 216.20 & & & & \\
\hline & divorced & 6 & 118.92 & & & & \\
\hline & Total & 275 & & & & & \\
\hline & single & 79 & 134.46 & 3 & 10.610 & .014 & 1-3, \\
\hline & married & 185 & 136.57 & & & & $2-3$ \\
\hline \multirow[t]{5}{*}{ Corrective discipline } & widowed & 5 & 252.40 & & & & $3-4$ \\
\hline & divorced & 6 & 133.33 & & & & \\
\hline & Total & 275 & & & & & \\
\hline & single & 79 & 130.52 & 3 & 9.946 & .019 & 1-3, \\
\hline & married & 185 & 138.41 & & & & $2-3$ \\
\hline \multirow[t]{3}{*}{ Total } & widowed & 5 & 246.00 & & & & $3-4$ \\
\hline & divorced & 6 & 133.92 & & & & \\
\hline & Total & 275 & & & & & \\
\hline
\end{tabular}

The Kruskal-Wallis H Test results on the scores taken by primary school teachers participating in the study on the preventive discipline, supportive discipline and corrective discipline sub-dimensions of the "Types of Discipline Scale Used by Teachers in Classroom Management" and the total scores taken from the scale by the variable of marital status are shown in Table 11. Accordingly, there is no significant difference between primary school teachers in the "supportive discipline [X2 (3)=5.639, P>.05]" sub-dimension of the "Scale on the Types of Discipline Used by Teachers in Classroom Management" by the variable of marital status.

According to Table 11, in terms of the marital status variable of primary school teachers, there is a significant difference between the scores of "preventive discipline $[\mathrm{X} 2(3)=8.741, \mathrm{P}<.05]$ " and "corrective discipline [X2 $(3)=10.610, \mathrm{P}<.05]$ " sub-dimensions of the "Scale of the Types of Discipline Used by Teachers in Classroom Management" and the overall score $[\mathrm{X} 2(3)=9.946, \mathrm{P}<.05]$ taken by primary school teachers by the marital status variable.

Comparison techniques were initialized in order to be able to determine from which groups the significant difference determined following the Kruskal-Wallis H-test results from. The Mann-Whitney U test preferred in the binary comparison was used to this end.

As a result of the analysis, it was found that the differences occur in favour of widowed teachers $(\mathrm{U}=68.30$; $\mathrm{p}<.05$ ) among single and widowed classroom teachers by the scores taken from the preventive discipline and corrective discipline sub-dimensions, and the total scores taken from the scale; in favour of widowed teachers $(\mathrm{U}=165.30 ; \mathrm{P}<.05)$ among married and widowed teachers; and again in favour of widowed teachers among widowed and divorced primary school teachers. Accordingly, it was found out that widowed teachers use preventive discipline and corrective discipline practices more than single, married and divorced teachers.

Table 12. The Kruskal-Wallis H Test results showing the differentiation of the perceptions of primary school teachers on the types of discipline they use in classroom management by the variable of education status

\begin{tabular}{ccccccc}
\hline Scale and Sub-dimensions & Education Status & $\mathrm{N}$ & Mean Rank & df & X2 & p \\
& associate degree & 14 & 113.46 & 2 & 2.377 & .305 \\
& bachelor's degree & 230 & 141.09 & & \\
Preventive discipline & master's degree & 31 & 126.15 & & .622 \\
& Total & 275 & & 2 & .733 \\
\hline \multirow{2}{*}{ Supportive discipline } & associate degree & 14 & 123.54 & & \\
& bachelor's degree & 230 & 139.43 & &
\end{tabular}




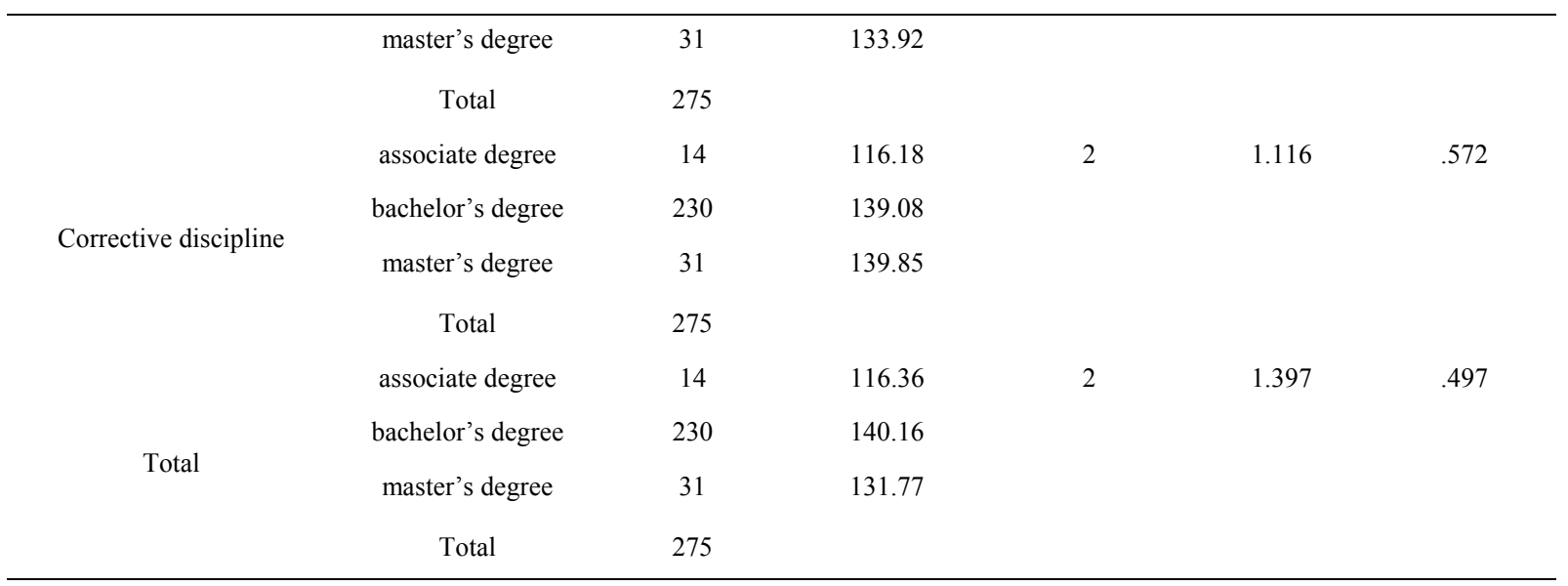

The Kruskal-Wallis H Test results on the scores taken by primary school teachers participating in the study from the preventive discipline, supportive discipline and corrective discipline sub-dimensions of the Scale on the Types of Discipline Used by Teachers in Classroom Management by the variable of the status of education and the total scores they obtained from the scale are shown in Table 12. Accordingly, there is no significant difference between the scores they obtained from the "preventive discipline [X2 (2)=2.377, P>.05]."; "supportive discipline [X2 (2)=.622, $\mathrm{P}>.05]$ " and "corrective discipline $[\mathrm{X} 2(2)=1.116, \mathrm{P}>.05]$ " sub-dimensions and the total score $[\mathrm{X} 2(5)=1.397, \mathrm{P}>.05]$ of the "Scale on the Types of Discipline Used by Teachers in Classroom Management" by the status of education.

Table 13. The Mann-Whitney U test results showing that the perceptions of primary school teachers regarding the types of discipline they use in classroom management vary by the variable of school type

\begin{tabular}{|c|c|c|c|c|c|c|}
\hline Scale and Sub-dimensions & School Type & $\mathrm{N}$ & Mean Rank & Sum of Ranks & $\mathrm{U}$ & $\mathrm{p}$ \\
\hline & state school & 250 & 134.51 & 33627.50 & 2252.500 & .021 \\
\hline \multirow[t]{3}{*}{ Preventive discipline } & private school & 25 & 172.90 & 4322.50 & & \\
\hline & Total & 275 & & & & \\
\hline & state school & 250 & 135.72 & 33930.00 & 2555.000 & .132 \\
\hline \multirow[t]{2}{*}{ Supportive discipline } & private school & 25 & 160.80 & 4020.00 & & \\
\hline & Total & 275 & & & & \\
\hline \multirow{4}{*}{ Corrective discipline } & state school & 250 & 137.10 & 34275.50 & 2900.500 & .553 \\
\hline & private school & 25 & 146.98 & 3674.50 & & \\
\hline & Total & 275 & & & & \\
\hline & state school & 250 & 135.61 & 33902.50 & 2527.500 & .115 \\
\hline \multirow[t]{2}{*}{ Total } & private school & 25 & 161.90 & 4047.50 & & \\
\hline & Total & 275 & & & & \\
\hline
\end{tabular}

The Mann-Whitney U test results on the scores taken by the primary school teachers participating in the study from the preventive discipline, supportive discipline and corrective discipline sub-dimensions of the "Scale on the Types of Discipline Used by Teachers in Classroom Management" by the variable of the type of school where they work and the total scores obtained from the scale are shown in Table 13. Accordingly, there is a significant difference in the "preventive discipline $(\mathrm{U}=2252.500, \mathrm{P}<.05)$ " sub-dimension of the "Scale on the Types of Discipline Used by Teachers in Classroom Management" by the variable of the type of school where they work. Accordingly, the perceptions of the primary school teachers working at private schools of preventive discipline are higher than those of the primary school teachers working at a state school. 
According to Table 13, there is no significant difference between the sub-dimension of "supportive discipline $(\mathrm{U}=2555.000, \mathrm{p}>.05)$ ", "corrective discipline $(\mathrm{U}=2900.500, \mathrm{p}>.05)$ " of the "Scale on the Types of Discipline Used by Teachers in Classroom Management" by the variable of the type of school where primary school teachers work and the overall scores obtained from the scale $(U=2527.500, p>.05)$.

Table 14. One-Way Variance Analysis (ANOVA) test results showing the differentiation of the perceptions of primary school teachers by the variable of professional seniority

\begin{tabular}{|c|c|c|c|c|c|c|}
\hline \multicolumn{2}{|c|}{ Scale and Sub-dimensions Source of the variance } & \multirow{2}{*}{$\begin{array}{c}\text { Sum of Squares } \\
.997\end{array}$} & \multirow{2}{*}{$\frac{\mathrm{df}}{4}$} & \multirow{2}{*}{$\begin{array}{c}\text { Mean of Squares } \\
.249\end{array}$} & \multirow{2}{*}{$\begin{array}{c}\mathrm{F} \\
1.087\end{array}$} & \multirow{2}{*}{$\begin{array}{c}\mathrm{p} \\
.363\end{array}$} \\
\hline & intergroup & & & & & \\
\hline \multirow[t]{3}{*}{ Preventive discipline } & intragroup & 61.881 & 270 & .229 & & \\
\hline & total & 62.878 & 274 & & & \\
\hline & intergroup & 1.644 & 4 & .411 & 1.985 & .097 \\
\hline \multirow[t]{2}{*}{ Supportive discipline } & intragroup & 55.912 & 270 & .207 & & \\
\hline & total & 57.556 & 274 & & & \\
\hline \multirow[b]{2}{*}{ Corrective discipline } & intergroup & 2.008 & 4 & .502 & 1.480 & .208 \\
\hline & intragroup & 91.559 & 270 & .339 & & \\
\hline & total & 93.567 & 274 & & & \multirow{4}{*}{.170} \\
\hline \multirow{3}{*}{ Total } & intergroup & 1.347 & 4 & .337 & 1.617 & \\
\hline & intragroup & 56.213 & 270 & .208 & & \\
\hline & total & 57.560 & 274 & & & \\
\hline
\end{tabular}

One-Way Variance Analysis ANOVA test results on the scores taken by primary school teachers participating in the study from the preventive discipline, supportive discipline and corrective discipline sub-dimensions of the "Scale on the Types of Discipline Used by Teachers in Classroom Management" by the variable of professional seniority and the total scores obtained from the scale are shown in Table 14. Accordingly, there is no significant difference between the scores they obtained from the "preventive discipline [F $(4,270)=1.087, \mathrm{P}>.05]$ "; "supportive discipline $[\mathrm{F}(4,270)=1.985, \mathrm{P}>.05]$ " and "corrective discipline $[\mathrm{F}(4,270)=1.480, \mathrm{P}>.05]$ " sub-dimensions and the total score $[\mathrm{F}(4,270)=1.617, \mathrm{P}>.05]$ of the Scale on the Types of Discipline Used by Teachers in Classroom Management" by professional seniority.

Table 15. The Kruskal-Wallis $\mathrm{H}$ test results showing the differentiation of the perceptions of primary school teachers by the variable of the period they work at their school

\begin{tabular}{|c|c|c|c|c|c|c|c|}
\hline $\begin{array}{c}\text { Scale and } \\
\text { Sub-dimensions }\end{array}$ & $\begin{array}{l}\text { Period They Work } \\
\text { at Their School }\end{array}$ & $\mathrm{N}$ & Mean Rank & $\mathrm{df}$ & $\mathrm{X} 2$ & $\mathrm{p}$ & $\begin{array}{l}\text { Significant } \\
\text { Difference }\end{array}$ \\
\hline \multirow{7}{*}{ Preventive discipline } & $1-3$ year & 149 & 132.9 & \multirow[t]{7}{*}{5} & \multirow[t]{7}{*}{9.383} & \multirow[t]{7}{*}{.095} & \multirow[t]{7}{*}{----- } \\
\hline & 4-7 year & 76 & 132.95 & & & & \\
\hline & 8-10 year & 25 & 144.38 & & & & \\
\hline & $11-15$ year & 14 & 162.36 & & & & \\
\hline & $16-20$ year & 6 & 215.83 & & & & \\
\hline & 21 and over & 5 & 176.70 & & & & \\
\hline & Total & 275 & & & & & \\
\hline \multirow{2}{*}{ Supportive discipline } & $1-3$ year & 149 & 131.36 & \multirow[t]{2}{*}{5} & \multirow[t]{2}{*}{13.236} & \multirow[t]{2}{*}{.021} & \multirow[t]{2}{*}{$1-5,2-5,3-5,4-5$} \\
\hline & 4-7 year & 76 & 131.51 & & & & \\
\hline
\end{tabular}




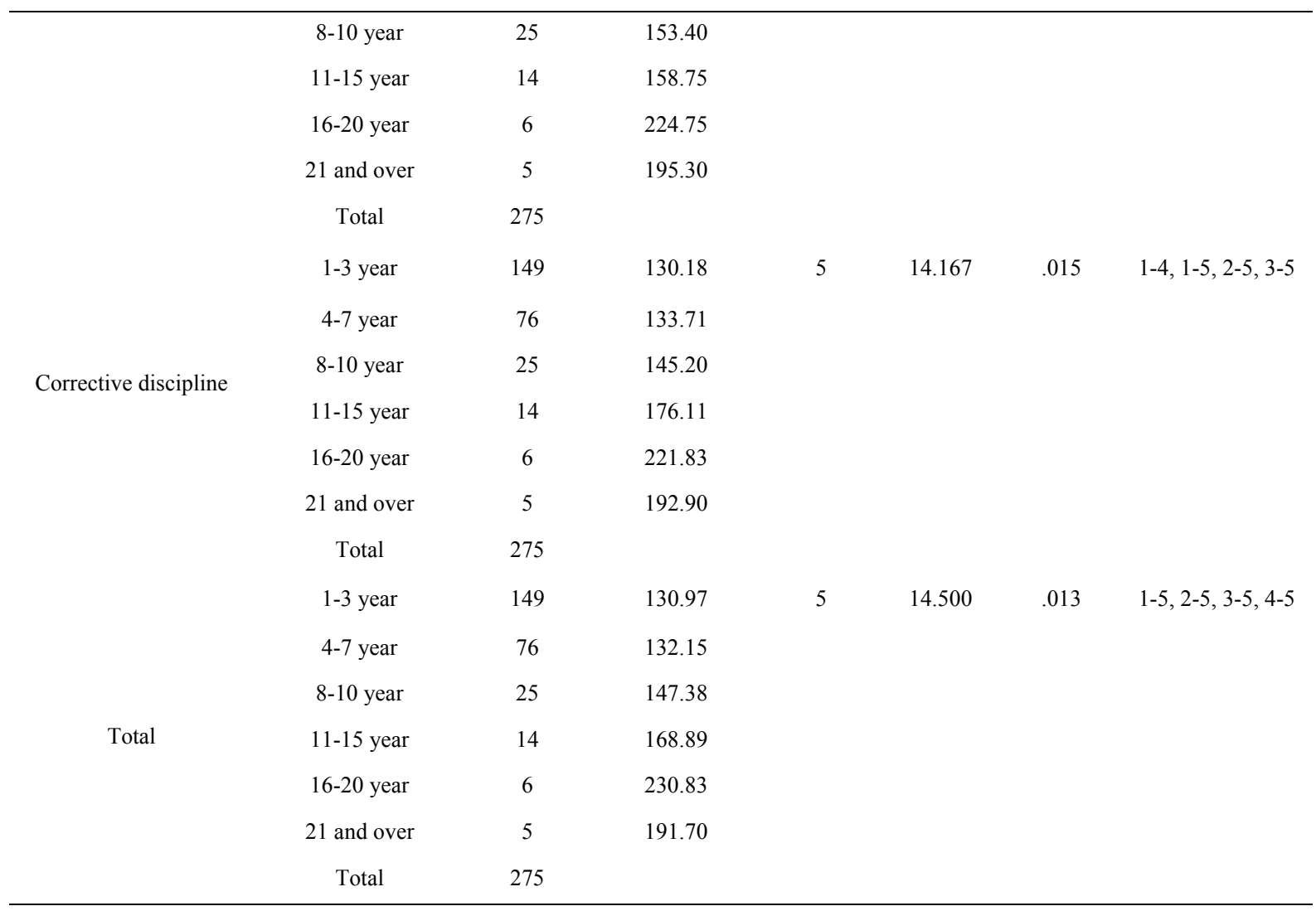

The Kruskal-Wallis $\mathrm{H}$ test results on the scores taken by primary school teachers participating in the study from the preventive discipline, supportive discipline and corrective discipline sub-dimensions of the "Scale on the Types of Discipline Used by Teachers in Classroom Management" by the variable of the period teachers work at their school and the total scores they obtained from the scale are shown in Table 15. Accordingly, there is no significant difference between the scores they obtained from the "preventive discipline $[\mathrm{X} 2(5)=9.383, \mathrm{P}>.05]$ " sub-dimension of the Scale on the Types of Discipline Used by Teachers in Classroom Management" by the variable of the period teachers work at their school.

According to Table 15, there is a significant difference between the sub-dimensions of "supportive discipline $[\mathrm{X} 2(5)=13.236, \mathrm{P}<.05]$ " and "corrective discipline $[\mathrm{X} 2(5)=14.167, \mathrm{P}<.05]$ " of the Scale on the Types of Discipline Used by Teachers in Classroom Management" and the total scores obtained from the scale [X2 $(3)=14.500, \mathrm{P}<.05]$ by the variable of the period primary school teachers work at their school.

Comparison techniques were initialized in order to determine from which groups the significant difference determined after the Kruskal-Wallis $\mathrm{H}$ test resulted from. The Mann-Whitney $\mathrm{U}$ test preferred in binary comparisons was applied to this end.

As a result of the analysis, it was found that the differences are in favour of the primary school teachers who worked at their school for 16-20 years between the primary school teachers who worked at their school for 1-3 years and those who worked for 16-20 years; they are in favour of the primary school teachers who worked at their school for 16-20 years between the primary school teachers who worked at their school for 4-7 years and those who worked for 16-20 years; they are in favour of the primary school teachers who worked at their school for 16-20 years between the primary school teachers who worked at their school for 8-10 years and those who worked for 16-20 years; they are in favour of the primary school teachers who worked at their school for 16-20 years between the primary school teachers who worked at their school for 11-15 years and those who worked for 16-20 years by the scores they obtained from the supportive discipline sub-dimension and the total score they obtained from the scale. Accordingly, it was concluded that teachers who worked at their school for 16-20 years prefer supportive discipline practices more than the teachers who worked for 1-3 years, 4-7 years, 8-10 years and 11-15 years at their school.

As a result of the analysis, it was determined that the differences are in favour of the primary school teachers who worked at their school for 11-15 years between the primary school teachers who worked at their school for 
1-3 years and those who worked for 11-15 years; they are in favour of the primary school teachers who worked at their school for 16-20 years between the primary school teachers who worked at their school for 1-3 years and those who worked for 16-20 years; they are in favour of the primary school teachers who worked at their school for 16-20 years between the primary school teachers who worked at their school for 4-7 years and those who worked for 16-20 years; they are in favour of the primary school teachers who worked at their school for 16-20 years between the primary school teachers who worked at their school for 8-10 years and those who worked for 16-20 years by the scores they obtained from the corrective discipline sub-dimension of the scale. Accordingly, it was concluded that teachers who worked at their school for 16-20 years prefer supportive discipline practices more than the teachers who worked for 1-3 years, 4-7 years and 8-10 years. Furthermore, it was also found that teachers who work at their school for 11-15 years prefer corrective discipline practices more than teachers working for 1-3 years at their school.

\section{Conclusion, Discussion and Suggestions}

As a result of the study, it was found out that the total perception of primary school teachers regarding the sub-dimensions of the types of discipline they use in classroom management, and their perception of the sub-dimensions of preventive discipline, supportive discipline and corrective discipline are at the level of "totally agree (always)". In general, teachers use all three types of discipline in classroom management. In this research, it was seen that primary school teachers prefer most the preventive discipline approach in classroom management, which is followed by the supportive discipline approach.

Kartal (2014) found that the perception of teachers in all dimensions of discipline types they use for classroom management is at the level of "frequently". While teachers always agreed with using "preventive" and "supportive" discipline types, they mostly agreed with using "improver" discipline type.

Clunies-Ross, Little, and Kienhuis (2008) investigated the relationship between primary school teachers' self-reported and actual use of classroom management strategies, and examined how the use of proactive and reactive strategies is related to teacher stress and student behaviour. The total sample consisted of 97 teachers from primary schools within Melbourne. The findings indicated that teacher self-reports accurately reflect actual practice, that relatively minor forms of student misbehaviours are a common concern for teachers, and that teachers are spending a considerable amount of time on behaviour management issues. The findings also revealed that the use of predominantly reactive management strategies has a significant relationship with elevated teacher stress and decreased student on-task behaviour.

The purpose of the study titled "Students' Perceptions of Classroom Behaviour Problems and the Effectiveness of Different Disciplinary Methods" was to examine students' perceptions of troublesome behaviour and the effectiveness of different disciplinary methods. To this end, 350 secondary school students completed the Classroom Behaviour Problems and Attitude Towards Disciplinary Methods questionnaire, and the results indicate that "talking out of turn" was the only behaviour perceived by both teachers and students to be most troublesome and most frequent. Deterrents that were perceived as most effective included being sent to the principal's office, detention, and getting an unfavourable report sent home. Regarding incentives, free time, a positive letter home, receiving a good mark, and getting a favourable academic report sent home were perceived to be most effective, while private praise and reprimands were also seen as an effective means for increasing appropriate behaviour. However, previous research suggests that teachers are choosing to use other strategies that are not seen by students as effective. Therefore, it was concluded that both teachers and students need to be educated regarding the results found in the current study, so that effective management strategies can be developed and used by teachers (Infantino \& Little, 2005).

In this research, the types of discipline used by primary school teachers in classroom management do not vary significantly by the variables of gender, age, education status and professional seniority.

In this research, the types of discipline used by primary school teachers in classroom management do not vary significantly by the variables of gender. Similar results to this study were achieved in the study of Esen (2006) and Kartal (2014), as well. Kartal (2014) found that teachers' perceptions relating sub-dimensions of discipline types they use for classroom management show no significant difference according to gender.

In this research, the types of discipline used by primary school teachers in classroom management do not vary significantly by the variables of education status. Similar results to this study were obtained in the study carried out by Kartal (2014). According to study of Kartal (2014) teachers' perceptions relating sub-dimensions of discipline types they use for classroom management show no significant difference according to education status. As distinct from the findings of our study, Esen (2006) found that primary school teachers who graduated from two-year higher education school use supportive discipline more than the primary school teachers who graduated 
from four-year teacher education high schools. Later in the study, it was found that teachers who graduated from two-year higher education schools use preventive discipline practices more than the teachers who graduated from four-year teacher high schools. No significant difference was achieved in other dimensions.

In this research, the types of discipline used by primary school teachers in classroom management do not vary significantly by the variables of professional seniority. Esen (2006) reached the conclusion that the sub-dimensions of the scale on the types of discipline teachers use in classroom management do not vary by the professional seniority variable. This finding supports our study. As distinct from the findings of our study, Kartal (2014) found that there is a difference between the teachers who have 1-5 years of work experience and the teachers who have 6-10 and 11-15 years of work experience in the "improver discipline" sub-dimension of discipline types teacher use for classroom management. It is found that teachers who have 6-10 years and 11-15 years of work experience use improver discipline more than the teachers who have 1-5 years of work experience.

In this research, the perceptions of the primary school teachers working at private schools of preventive discipline are higher than those of the primary school teachers working at a state school. At the same time, there is no significant difference between the sub-dimension of "supportive discipline", "corrective discipline" and the overall scores obtained from the scale by the variable of the type of school where primary school teachers work.

In this research, widowed teachers prefer the preventive discipline and corrective discipline practices more than single, married and divorced teachers.

In this research, teachers who worked at their school for 16-20 years prefer supportive discipline practices more than teachers who worked at their school for 1-3 years, 4-7 years, 8-10 years and 11-15 years. Teachers who worked at their school for 16-20 years prefer corrective discipline practices more than the teachers who worked at their school for 1-3 years, 4-7 years, and 8-10 years. Furthermore, teachers who worked at their school for 11-15 years prefer corrective discipline practices more than the teachers who worked at their school for 1-3 years.

As distinct from the findings of our study, Kartal (2014) found that teachers' perceptions relating sub-dimensions of discipline types they use for classroom management show no significant difference according to variable of period they work at their school.

The following suggestions are mentioned in the line with findings of the research:

In further studies, the perceptions of primary school teachers regarding the types of discipline they use in classroom management can be examined in terms of different variables.

This study includes the primary school teachers in Istanbul. In further studies, the study can be applied to the primary schools across Turkey by expanding the sample group.

Primary school teachers working at primary schools constitute the sample of this study. In further studies, the discipline perceptions of the educators working at secondary schools, high schools and higher education can be examined by different variables.

This study is a quantitative study. Qualitative studies or studies where quantity and quality co-exist can be carried out.

Any kind of guidance study can be provided under the coordination of the school managements in order to ensure that teachers use supportive, corrective and preventive discipline approach in classroom management. Educative seminars can be provided on this subject.

New comparative studies that include the relation between the types of discipline used by teachers in classroom management and the relevant variable to be determined can be carried out.

\section{References}

Aydın, B. (2001). İlköğretim okullarında sınıf disiplinin sağlanması. Yayımlanmamış Doktora Tezi, Abant İzzet Baysal Üniversitesi Sosyal Bilimler Enstitüsü, Bolu.

Bal, T. (2005). İlkögretim 4. ve 5. sinıf öğretmenlerinin disiplin anlayışlarl ve kullandlkları disiplin yöntemleri (Konya ili örneği) The understanding and methods of discipline of the 4th and 5th class teachers in primary schools (Konya city example). Yüksek Lisans Tezi, Selçuk Üniversitesi, Sosyal Bilimler Enstitüsü, Konya.

Başar, H. (2008). Eğitim ve Sınıf Yönetimi. In A. Esmahan (Ed.), Sinıf Yönetimi içinde. Anadolu Üniversitesi Yayınları.

Büyüksarı, A. (2015). Okul yöneticilerinin disiplin yaklaşımları (Disciplinary approaches of school administrators). Yüksek Lisans Tezi, İstanbul Aydın Üniversitesi, Sosyal Bilimler Enstitüsü, İstanbul. 
Clark, C. (1998). Discipline in Schools. British Journal of Educational Studies, 46(3), 298-301. https://doi.org/10.1111/1467-8527.00085

Clunies, R. P., Little, E., \& Kienhuis, M. (2008). Self-reported and actual use of proactive and reactive classroom management strategies and their relationship with teacher stress and student behaviour. Educational Psychology, 28(6), 693-710. https://doi.org/10.1080/01443410802206700

Çimen, K. L., \& Karaboğa, Y. (2015). Yönetici ve Öğretmenlerin Ortaöğretim Okullarındaki Disiplin Sorunlarına İlişkin Görüşleri (The Opinion of Managers and Teachers on Discipline Problems at Elementary Schools). International Journal of Science Culture and Sport (IntJSCS), July Special Issue 3, 613-628. https://doi.org/10.14486/IJSCS327

Emmer, E. T., \& Stough, L. M. (2001). Classroom Management: A Critical Part of Educational Psychology, with Implications for Teacher Education. Educationalo Psychologist, 36(2), 103-112. https://doi.org/10.1207/S15326985EP3602_5

Erden, M. (2008). Sinıf yönetimi. İstanbul: Epsilon Yayınları.

Esen, H. (2006). Illk ve ortä̈ğretim okullarında görev yapan ögretmenlerin kullandıkları disiplin türleri. Yayımlanmamış Yüksek Lisans Tezi, Trakya Üniversitesi Sosyal Bilimler Enstitüsü, Edirne.

Güner, Ü. (2009). Meslek liselerinde görev yapan ögretmenlerin disiplin anlaylşlarl ve disiplin uygulamalarl/The discipline apprehensions and appliances of vocational school teachers. Yüksek Lisans Tezi, Yeditepe Üniversitesi, Sosyal Bilimler Enstitüsü, İstanbul.

Güzel, H. (2014). Din Kültürü ve Ahlak Bilgisi öğretmenlerinin disiplini bozan öğrenci davranışlarına karşı tutumlart (Religion and Ethics Teachers' attitudes towards students involved in disciplinary misconduct). Yüksek Lisans Tezi, Marmara Üniversitesi, Sosyal Bilimler Enstitüsü, İstanbul.

Hart, R. (2010). Classroom behaviour management: Educational psychologists' views on effective practice. Emotional and Behavioral Difficulties, 15(4), 353-371. https://doi.org/10.1080/13632752.2010.523257

Hayes, B., Hindle, S., \& Withington, P. (2007). Strategies for Developing Positive Behaviour Management, Teacher Behaviour Outcomes and Attitudes to the Change Process. Educational Psychology in Practice, 23(2), 161-175. https://doi.org/10.1080/02667360701320861

Helvacı, M. A. (2010). Sınıfta iletişim ve disiplin oluşturma. In G. Celal (Ed.), Kuram ve uygulamada sınıf yönetimi (pp. 127-159). içinde. Ankara: Anı Yayıncıllk.

Infantino, J., \& Little, E. (2005). Students' Perceptions of Classroom Behaviour Problems and the Effectiveness of Different Disciplinary Methods. Educational Psychology, 25(5), 491-508. https://doi.org/10.1080/01443410500046549

İnce, B. (2011). Sinıfta istenmeyen davranışlara karşı öğretmenlerin disiplin uygulamalarıyla ilgili ilköğretim 5. sınıf ögrrencilerinin görüşlerinin incelenmesi. Yayımlanmamış Yüksek Lisans Tezi, Marmara Üniversitesi Eğitim Bilimleri Enstitüsü, İstanbul.

Karasar, N. (2012). Bilimsel araştırma yöntemi. Ankara: Nobel Yayıncılık.

Kartal, V. (2014). Ortaokul ögretmenlerinin okul kültürü alglları ile sinıf yönetiminde kullandıkları disiplin türleri algıları arasindaki ilişki (The relationship between secondary school teachers' perception of school culture and the perception of discipline types they use for classroom management). Yüksek Lisans Tezi, Abant İzzet Baysal Üniversitesi, Bolu.

Kılbaş, Ş. (2006). Sinıf yönetiminde yeni yaklaşımlar. İstanbul: Kare Yayınları.

Koç, E. (2011). Öğretmen adaylarının sınıf yönetiminde kullanılan disiplin modellerine ilişkin görüşleri (Opinions of prospective teachers on disiplinary models used in class management). Yüksek Lisans Tezi, Gazi Üniversitesi, Eğitim Bilimleri Enstitüsü, Ankara.

Luiselli, J. K., Putnam R. F., Handler M. W., \& Feinberg, A. B. (2005). Whole-school positive behaviour support: Effects on student discipline problems and academic performance. Educational Psychology, 25(2-3), 183-198. https://doi.org/10.1080/0144341042000301265

MacAllister, J. (2013). School Discipline, Educational Interest and Pupil Wisdom. Educational Philosophy and Theory, 45(1), 20-35. https://doi.org/10.1080/00131857.2012.711902

MacAllister, J. (2014). Why discipline needs to be reclaimed as an educational concept. Educational Studies, 40(4), 438-451. https://doi.org/10.1080/03055698.2014.930341 
Maguire, M., Ball, S., \& Braun, A. (2010). Behaviour, classroom management and student "control": Enacting policy in the English secondary school. International Studies in Sociology of Education, 20(2), 153-170. https://doi.org/10.1080/09620214.2010.503066

Mert, M. (2014). Okul yöneticilerinin mizah tarzları ve disiplin anlayışları arasındaki ilişskinin ögrretmen görüşleri açısindan incelenmesi (The examination of the relationship between school administrators' humor style and sense of discipline in terms of teachers' perception). Yüksek Lisans Tezi, Erciyes Üniversitesi, Eğitim Bilimleri Enstitüsü, Konya.

O'Neill, S. C., \& Stephenson, J. (2011). The measurement of classroom management self-efficacy: A review of measurement instrument development and influences. Educational Psychology, 31(3), 261-299. https://doi.org/10.1080/01443410.2010.545344

Payne, R. (2015). Using rewards and sanctions in the classroom: Pupils' perceptions of their own responses to current behaviour management strategies. Educational Review, 67(4), 483-504. https://doi.org/10.1080/00131911.2015.1008407

Tosun, Ü. (2001). Öğretmenlerin disipline ilişkin tutumlar ve toplam kalite modelinde disiplin anlaylşl (Teachers attitudes related to discipline and the discipline approach within the framework of total quality). Doktora tezi, Marmara Üniversitesi, Eğitim Bilimleri Enstitüsü, İstanbul.

Uysal, G. (1991). Ortaögretim kurumlarında disiplin yönetmeliği hükümlerine göre disiplin uygulamalarının değerlendirilmesi, Evaluation of The Practice of Disciplinary Punishment According to The Provisions of Disciplinary Regulations in Secondary Educational Institutions. Yüksek Lisans Tezi, Ankara Üniversitesi, Sosyal Bilimler Enstitüsü, Ankara.

Vatansever-Bayraktar, H. (2015). Sınıf Yönetiminde Öğrenci Motivasyonu ve Motivasyonu Etkileyen Etmenler (Student Motivation in Classroom Management and Factors That Affect Motivation). Turkish Studies-International Periodical for the Languages, Literature and History of Turkish or Turkic, 10(3), 1069-1090.

Vatansever-Bayraktar, H., \& Kaya, M. (2016). Okul yöneticilerinin okuldaki disiplin sorunlarıyla ilgili tutumlarının incelenmesi (Investigation of school administrators' attitude with discipline problems). In Proceeding Book (p. 1216). International Conference on Quality on Higher Education, Sakarya University,

Visser, J. (2005). Key factors that enable the successful management of difficult behaviour in schools and classrooms. International Journal of Primary, Elementary and Early Years Education, 33(1), 26-31. https://doi.org/10.1080/03004270585200061

Yalçınkaya, M., \& ve Küçükkaragöz, H. (2006). Sınıfta disiplin kuralları belirleme ve uygulaması. In M. Yılman (Ed.), Sinıf yönetimi (pp. 101-130). İçinde. Ankara: Nobel Yayın Dağııımcılık.

Yavuzer, H. (2003). Çocuğu tanımak ve anlamak. İstanbul: Remzi Kitabevi Yayını.

Yılmaz, N. (2007). Sinıf öğretmenlerinin sınıf içi disiplini sağlamada kullandıkları ödül ve ceza yöntemlerinin değerlendirilmesi (İstanbul ili Pendik ilçesi örneği)-Assesment of the award and punishment methods used by the class teachers to ensure disipline in the class. Yüksek Lisans Tezi, Yeditepe Üniversitesi, Sosyal Bilimler Enstitüsü, İstanbul.

Yiğit, B. (2004). Sınıfta disiplin ve öğrenci davranışının yönetimi. In M. Şişman, \& S. Turan (Eds.), Sinıf yönetimi (pp. 155-179). İçinde. Ankara: Pegem A Yayıncılık.

\section{Copyrights}

Copyright for this article is retained by the author(s), with first publication rights granted to the journal.

This is an open-access article distributed under the terms and conditions of the Creative Commons Attribution license (http://creativecommons.org/licenses/by/4.0/). 